\title{
Factor XI deficiency in Indian Bos taurus, Bos indicus, Bos taurus $x$ Bos indicus crossbreds and Bubalus bubalis
}

\author{
Rajesh K. Patel ${ }^{1}$, Kalpesh J. Soni ${ }^{1}$, Jenabhai B. Chauhan ${ }^{1}$, Krishna M. Singh ${ }^{1}$ \\ and Krothapalli R.S. Sambasiva Rao ${ }^{2}$ \\ ${ }^{1} R \& D$-Biotechnology, National Dairy Development Board, Anand, India. \\ ${ }^{2}$ Centre for Biotechnology, Acharya Nagarjuna University, Nagarjunanagar, India.
}

\begin{abstract}
We investigated the occurrence of Factor XI (FXI) deficiency syndrome in the following Indian dairy animals: Bos taurus Holstein-Friesian and Jersey cattle, Bos indicus Indian cattle breeds, $B$. taurus $\times$ B. indicus crossbreds and the river buffalo Bubalus bubalis. Factor XI deficiency is an autosomal recessive bleeding disorder known to affect Holstein cattle worldwide. A total of 1001 dairy animals, mainly bulls, were genotyped to detect the mutation within exon 12 of the gene encoding for factor XI. Two Holstein bulls were detected as heterozygous (carrier) for FXI deficiency, giving a carrier frequency of $0.6 \%$ in Indian Holstein cattle. None of the other cattle or buffalo breeds was found to be a carrier for $\mathrm{FXI}$. Sequence comparison between normal and heterozygous animals revealed that there is a 77 base pair insertion fragment (AT (A)29 TAAAG (A)27 GAATTATTAATTCT) within exon 12 of the FXI gene. Both sequences were submitted to the National Center for Biotechnology Information (NCBI) GenBank and assigned the accession numbers DQ438908 for normal Holstein Friesian animals and DQ438909 for heterozygous Holstein Friesian animals.
\end{abstract}

Key words: autosomal recessive disease, blood coagulation, buffaloes, Factor XI, Holstein-Friesian dairy cattle.

Received: May 15, 2006; Accepted: April 23, 2007.

Factor XI (FXI) is one of more than a dozen proteins involved in the early blood coagulation cascade (Brush et al., 1987), FXI-deficiency syndrome being an autosomal recessive bleeding disorder first discovered in Holstein cattle in Ohio (Kociba et al., 1969) but also reported in many other countries, including, but not only, Canada (Gentry et al., 1975), England (Brush et al., 1987) and Japan (Kunieda et al., 2005). Bovines with FXI-deficiency may have lower calving and survival rates and increased susceptibility to infectious diseases (Liptrap et al., 1975). The 3' end of the gene for bovine FXI is located on bovine chromosome 17 and was first characterized by Robinson et al., (1997). Kunieda et al., (2005) isolated and sequenced the entire 8910 bp coding region, comprising 15 exons and 14 introns, of the Japanese black cattle bovine FXI gene in bovines. In India, however, there has been no reported incidence of FXI-deficiency but since Holstein-Friesian Bos taurus cattle are extensively used for crossbreeding with many indigenous Indian Bos indicus cattle it is mandatory to screen breeding bulls, especially Holstein-Friesian and Holstein-Friesian crossbred bulls, for FXI-deficiency along with the ongoing screening for bovine leukocyte adhesion

Send correspondence to R.K. Patel. National Dairy Development Board, 388001 Anand, India. E-mail: rkpatel46@yahoo.com. deficiency syndrome (BLAD), deficiency of uridine monophosphate synthase (DUMPS) and citrullinaemia in order to prevent the propagation of these genetic diseases in the Indian cattle population.

We examined a panel of 1001 dairy bulls made up of various breeds of exotic (B. taurus) cattle, native $B$. indicus zebu cattle, $B$. taurus $\times$ B. indicus crossbreds and water buffalo (Bubalus bubalis) is maintained at different semen production centers and breeding farms across India country (Table 1).

Blood samples $(5 \mathrm{~mL})$ were collected in heparinized tubes from each bovine by jugular veinipuncture. For genomic DNA extraction, blood samples were lysed, washed with $40 \mathrm{~mL}$ of lysing solution $(0.32 \mathrm{M}$ sucrose, $10 \mathrm{mM}$ tris- $\mathrm{HCl}$ with $\mathrm{pH} 8.0,5 \mathrm{mM} \mathrm{MgCl} 2$ and $1 \%$ triton $\mathrm{X}-100$ ) and pelleted by centrifugation. The leukocyte pellet was resuspended in $4 \mathrm{~mL}$ of nucleus lysis buffer $(75 \mathrm{mM} \mathrm{NaCl}$ and $24 \mathrm{mM}$ EDTA) plus $400 \mu \mathrm{L}$ of $20 \%(\mathrm{v} / \mathrm{v})$ sodium dodecyl sulfate $(80 \mathrm{mg})$ and $25 \mu \mathrm{L}$ of $20 \mathrm{mg} \mathrm{mL}^{-1}(500 \mu \mathrm{g})$ proteinase $\mathrm{K}$ (Genei, Banglore, India) and incubated overnight at $37^{\circ} \mathrm{C}$, after which the DNA was prepared by the organic extraction method described by Sambrook et al. (1989). The quantity of genomic DNA was determined spectrophotometrically and its quality by agarose 
Table 1 - Details of the samples collected from different breeds of Bos taurus, Bos indicus and B. taurus $x$ B. indicus crossbred cattle and the river buffalo Bubalus bubalis. (All the animals were bulls).

\begin{tabular}{|c|c|c|}
\hline Breeds & $\begin{array}{l}\text { Number } \\
\text { of samples }\end{array}$ & $\begin{array}{l}\text { Number of FXI } \\
\text { mutants detected }\end{array}$ \\
\hline \multicolumn{3}{|l|}{ Cattle } \\
\hline \multicolumn{3}{|l|}{ B. taurus } \\
\hline Holstein Friesian & 330 & 2 \\
\hline Holstein Friesian x $B$. indicus & 265 & none \\
\hline Jersey & 105 & none \\
\hline Jersey x B. indicus & 69 & none \\
\hline \multicolumn{3}{|l|}{ B. indicus } \\
\hline Kankrej & 23 & none \\
\hline Redsindhi & 16 & none \\
\hline Khillari & 13 & none \\
\hline Gir & 11 & none \\
\hline Sahiwal & 5 & none \\
\hline Haryana & 4 & none \\
\hline Deoni & 3 & none \\
\hline Red Khandhari & 3 & none \\
\hline Dangi & 1 & none \\
\hline \multicolumn{3}{|l|}{ River buffaloes } \\
\hline \multicolumn{3}{|l|}{ Bubalus bubalis } \\
\hline Murrah & 56 & none \\
\hline Surti & 46 & none \\
\hline Pandharpuri & 34 & none \\
\hline Mehsana & 15 & none \\
\hline Jaffarabadi & 2 & none \\
\hline Total & 1001 & 2 \\
\hline
\end{tabular}

gel-electrophoresis, both by standard methods, prior to PCR amplification.

The insertion mutation within exon 12 was detected using the PCR assay described by Marron et al., (2004) with minor modifications. The PCR assay was set up under sterile conditions in $200 \mu \mathrm{L}$ capacity PCR tubes containing $100 \mathrm{ng}$ of genomic DNA template, $0.4 \mathrm{pM}$ each of forward (5'CCCACTGGCTAGGAATCGTT3') and reverse (5'CAAGGCAATGTCATATCCAC3') primers, 1X PCR buffer (10 mM Tris-Cl: $\mathrm{pH}-9.0,50 \mathrm{mM} \mathrm{KCl}$, $0.01 \%$ gelatin and $\left.1.5 \mathrm{mM} \mathrm{MgCl}_{2}\right), 400 \mu \mathrm{M}$ of each dNTP and 1 unit of Taq DNA polymerase (Genei, Banglore, India) in a final reaction volume of $25 \mu \mathrm{L}$. The PCR was carried out using a Biometra T1 Thermocycler and the following protocol: initial denaturation at $94{ }^{\circ} \mathrm{C}$ for $3 \mathrm{~min}$ followed by 30 cycles of $94{ }^{\circ} \mathrm{C}$ for $1.5 \mathrm{~min}$, annealing of primers at $55{ }^{\circ} \mathrm{C}$ for $1 \mathrm{~min}$ and extension at $72{ }^{\circ} \mathrm{C}$ for $2 \mathrm{~min}$, followed by final extension at $72{ }^{\circ} \mathrm{C}$ for $10 \mathrm{~min}$. The amplification products were separated in $2.5 \%(\mathrm{w} / \mathrm{v})$ agarose gels, stained with ethidium bromide and viewed under UV light. The amplification products were commercially cloned and sequenced at Genei, Bangalore, India. A $320 \mathrm{bp}$ amplification product, identified as the carrier for FXI-deficiency, and a 244 bp normal FXI product were purified using a PCR product purification kit (Genei, Bangalore, India) and cloned in a pDK101-based (a modified pGEM 2T) T/A cloning vector. The clones were confirmed by insert release using the Nco I restriction enzyme (Genei, Banglore, India). The cloned DNA was sequenced using a vector specific primer (M13U18) in an automated DNA sequencer with fluorescent dye terminator (ABI 3100, Applied Biosystems, California). The sequence obtained in our study was then compared with the GenBank database using the basic local alignment search tool (BLAST) program of the National Center for Biotechnology Information (NCBI).

Agarose gel-electrophoresis analysis of the amplified product from 999 of the bovines tested revealed only a 247 bp normal FXI fragment while two Holstein-Friesian animals exhibited both $247 \mathrm{bp}$ and the 324 bp FXI-deficiency fragments (Figure 1), indicating that these animals both carried the Holstein-Friesian mutation in the FXI gene. The frequency of carrier bovines in Indian HolsteinFriesian cattle was, therefore, $0.6 \%$.

To confirm the FXI gene mutation, the PCR amplicon was successfully cloned into the pDK101-based T/A cloning vector, which was transformed in $\mathrm{DH}_{5}$ alpha competent cells. The clones were confirmed by plasmid DNA isolation followed by release of the insert (244 bp and $320 \mathrm{bp}$ ) using the Nco I restriction endonuclease (Genei, Banglore, India). The single-strand of the entire clone (insert + vector) was sequenced using the M13U18 vector specific primer (Genei, Banglore, India). After screening for vector contamination, 247 bases and 324 bases were obtained which and subjected to BLAST analysis to find the region of local similarity between sequences. The BLAST search revealed 98\% homology with the factor XI gene of Bos taurus followed by Bubalus bubalis. The final $247 \mathrm{bp}$ (Normal) and 324 bp (Carrier) bovine FXI gene sequences were submitted to NCBI and assigned the GenBank accession numbers DQ438908 and DQ438909 respectively. The complementary strand was not sequenced.

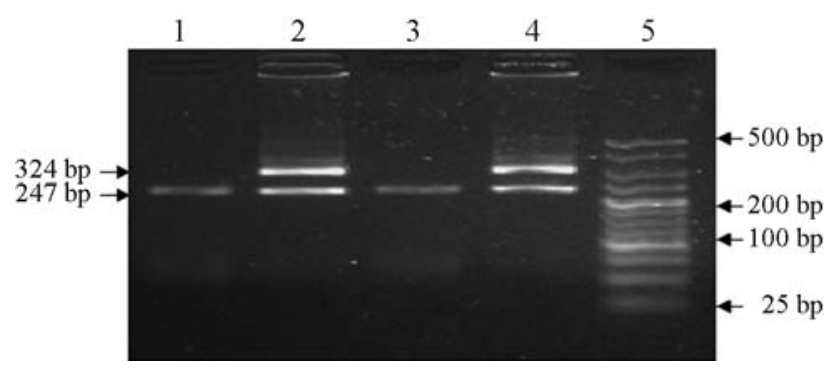

Figure 1 - Electrophoretogram of PCR product generated by amplification of genomic DNA using gene specific primers. Lane 1 and 3 \# 247 bp fragment of normal animal, lane 2 and 4 \# $324 \mathrm{bp}$ and $247 \mathrm{bp}$ fragments of carrier animals, lane $5 \# 25$ bp DNA ladder. 


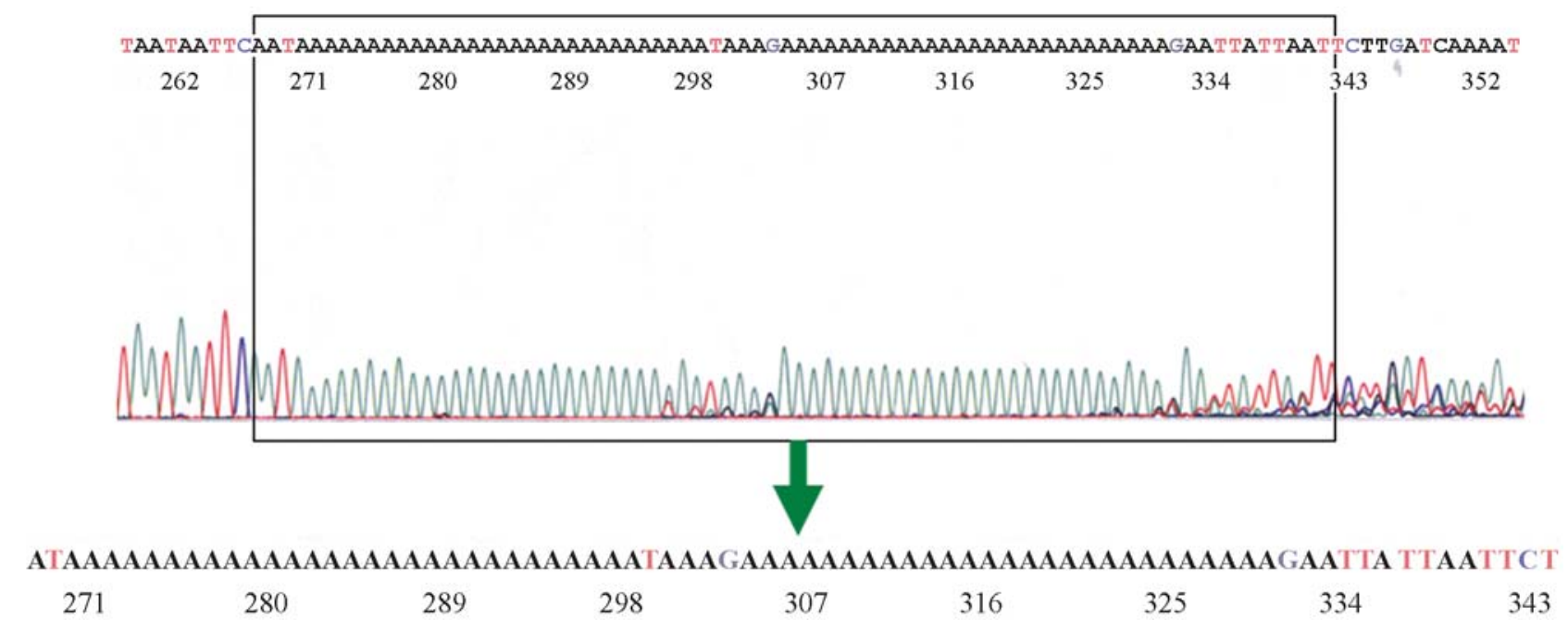

Figure 2 - Electropherogram showing fragment of 77 bases insertion mutation within exon 12 of the factor XI mutated allele from carrier HolsteinFriesian cattle.

In this study a total of 1001 dairy bulls were screened for FXI-deficiency but only two were found to carry the mutant FXI gene. One carrier was a three-year old Holstein-Friesian bull from a farm in southern India. To study the mechanism of FXI-deficiency inheritance we examined the pedigree of this bull and found that it was sired by artificial insemination using semen imported from Denmark, the dam exhibiting the normal FXI genotype. This suggests that the mutant allele could be transmitted from the sire. The other carrier was an 18-month old Holstein-Friesian bull from a farm in western India. A detailed inheritance pattern study revealed a normal sire genotype but the halfsib progeny of the FXI-carrier animal revealed that the possible mode of inheritance could be from the dam only. Unfortunately, the dam could not be genotyped because it had previously died. At $0.6 \%$ the frequency of FXI-deficiency carriers in the Holstein-Friesian population observed in our study is half that of the $1.2 \%$ reported in the Holstein sire population of the USA (Marron et al., 2004). The mutant gene for factor XI deficiency in Indian Holstein-Friesian cattle was higher than citrullinaemia (Murleedharan et al., 1999; Patel et al., 2006) and very much lower than BLAD (Patel et al., 2007), other autosomal recessive genetic diseases observed in Indian Holstein population. Because of the paucity of literature regarding the molecular diagnosis of FXI-deficiency, it is difficult to compare the carrierfrequency in the Indian Holstein-Friesian population to that found in other countries. In our study, sequence analysis of the single strand revealed a stop codon within the first four bases in the insertion followed by poly-adenine residues. The truncated protein could be missing the entire serine protease domain (Asakai, 1987). Sequencing of the PCR product followed by vector contamination revealed $247 \mathrm{bp}$ and $324 \mathrm{bp}$ fragments in normal and heterozygous carrier animals respectively, clearly suggesting that the PCR prod- uct size is not similar to the 244 and 320 bp bases reported by Marron et al., (2004). One of the interesting findings in our study is that there was a $77 \mathrm{bp}$ insertion (AT (A)29 TAAAG (A)27 GAATTATTAATTCT) in the exon 12 of the bovine FXI gene, the partial sequence of this insertion being shown in Figure 2). This contrasts with the findings of Maroon et al. (2004) who reported a 76 bp insertion in American Holstein cattle. Heterozygous bovines show varying symptoms and degree of reduced FXI activity (Gentry and Black, 1980), but this is difficult to distinguish because of the overlap in the normal and carrier activity ranges.

The occurrence of FXI-deficiency in two Indian Holstein-Friesian bulls is alarming and emphasizes the need for the regular genotyping of breeding bulls, especially Holstein-Friesian cattle and their crossbreds, for FXI-deficiency along with the ongoing screening for BLAD, citrullinaemia and DUMPS before induction of bulls into artificial insemination and crossbreeding programs.

\section{Acknowledgments}

The authors are grateful to the management of the Indian National Dairy Development Board (NDDB) for providing research facility.

\section{References}

Asakai R, Davie EW and Chung DW (1987) Organization of the gene for human factor XI. Biochem 26:7221-7228.

Brush PJ, Anderson PH and Gunning RF (1987) Identification of factor XI deficiency in Holstein-Friesian cattle in Britain. Vety Rec 121:14-17.

Gentry PA, Crane S and Lotz S (1975) Factor XI (plasma thromboplastin antecedent) deficiency in cattle. Canad Vety J 16:160-163.

Gentry PA and Black BD (1980) Prevalence and inheritance of factor XI (plasma thromboplastin antecedent) deficiency in cattle. J Dairy Sci 63:616-620. 
Kociba GJ, Ratnoff OD, Loeb WF, Wall RL and Heider LE (1969) Bovine plasma thromboplastin antecedent (Factor XI) deficiency. J Lab and Clin Med 74:37.

Kunieda M, Tsuji T, Abbasi AR, Khalaj M, Ikeda M, Miyadera K, Ogawa $\mathrm{H}$ and Kunieda $\mathrm{T}$ (2005) An insertion mutation of the bovine F11 gene is responsible for factor XI deficiency in Japanese black cattle. Mamm Genom 16:383-389.

Liptrap RM, Gentry PA, Ross ML and Cummings E (1995) Preliminary findings of altered follicular activity in Holstein cows with coagulation factor XI deficiency. Vety Res Commun 19:463-471.

Marron BM, Robinson JL, Gentry PA and Beever JE (2004) Identification of a mutation associated with factor XI deficiency in Holstein cattle. Anim Genet 35:454-456.

Muraleedharan P, Khoda VK, Grupe S, Mukhopadhyaya PN, Manfred S and Mehta HH (1999) Incidence of hereditary citrullinaemia and bovine leukocyte adhesion deficiency syndrome in Indian dairy cattle (Bos taurus, Bos indicus) and buffalo (Bubalus bubalis) population. Arch Tierz Dummerstorf 42:347-352.

Patel RK, Singh KM, Soni KJ, Chauhan JB and Sambasiva Rao KRS (2006). Lack of carriers of Citrullinaemia and DUMPS in Indian Holstein cattle. J Appl Genet 47:239-242.

Patel RK, Singh KM, Soni KJ, Chauhan JB and Sambasiva Rao KRS (2007). Low incidence of bovine leukocyte adhesion deficiency (BLAD) carriers in Indian cattle and buffalo breeds. J Appl Genet 48:153-155.

Robinson JL, Beever JE, De Leuw N, Lewin HA, Gillings M, Dennis JA and Healy PJ (1997) characterization of the 3' end of the gene for Factor XI. J Dairy Sci 81:539-543.

Sambrook J, Fritsch EF and Maniatis T (1989) Molecular Cloning: A Laboratory Manual. $2^{\text {nd }}$ edition. Cold Spring Harbor Laboratory Press, New York.

Associate Editor: Luiz Lehmann Coutinho 